\title{
Economic Growth and Deforestation: a Study of Changes in Land Coverage in West Nusa Tenggara Province
}

\author{
James Sinurat ${ }^{1}$, Yunus Arifien ${ }^{2}$ \\ \{yunus@unb.ac.id ${ }^{2}$ \} \\ University of Nusa Bangsa ${ }^{1,2}$
}

\begin{abstract}
In every region that is transitioning from agrarian economic activity to industrial economic activity, it is always faced with deforestation or changes in forest cover, including in West Nusa Tenggara. This study aims to determine the effect of economic growth and population on land cover change and deforestation in West Nusa Tenggara Province. The research was conducted in March - August 2020, which consisted of activities to determine land cover changes through processing satellite image data, which was matched with data from BPS. Data on economic growth and population are obtained from BPS. Modeling with multiple linear regression. The results of regression modeling show that economic growth and population growth significantly increase land for building and reduce forest land cover.
\end{abstract}

Keywords: Economic growth, deforestation, poverty, land cover

\section{Introduction}

Population and development are two things that cannot be separated, because development cannot occur without residents, nor will the population prosper without development. Every year about 80 million new residents are born and increase the number of the world's population which now numbered billions, most of the $97 \%$ population increase comes from third world countries. The world population is expected to increase to 8.1 Trillion in 2025 and 9.6 Trillion in 2050 [1]. The increase in population and increased socio-economic activities resulted in increased dependence on forests and land [2].

An economy can produce goods and services, so a definite production process is needed to use and process natural resources by using capital tools, and at a certain level of technology, as well as experts, certain humans (natural recource base of development in natural resource processing) or often called as the main production factor. By increasing production, it will indirectly encourage consumption in the aggregate. The continuous increase in consumption and production will trigger economic growth that will run in the long term [3].

The socio-economic conditions of the community that affect the conversion of community forests to the use of shifting cultivation. Farmers' income from community forestry businesses and income from former community forest lands that were used as shifting cultivation activities. The lower the income from community forestry businesses and the higher the income from shifting cultivation, the higher the rate of community forest conversion. In addition to economic 
factors that affect farmers converting community forests, it is also influenced by the area of land they control, and the number of people working in the sector [4].

Forest and land resources are resources that become a mainstay in people's socio-economic activities, especially in developing countries. Therefore, in the last decade developing countries have become the focus of developed countries in terms of changes in environmental quality related to changes in function and degradation of forests and land. "Correct" management will have broad and long-term impacts, and vice versa, errors in bio-physical forest management can lead to land degradation, and even have broad, social, economic, and even political impacts.

Forest cover in all regions has a tendency to decline from year to year. After the Reformation, in 2000 natural forest cover was 106.4 million hectares, then the remaining forest declined during the second period of the SBY administration in 2009 with an area of 93 million hectares. As of 2017, during the Jokowi administration, the remaining natural forest cover was 82.8 million hectares or around 43 percent of Indonesia's land area [5].

Indonesia's deforestation in 2017-2018 is 0.44 million ha. Based on forest type, the highest deforestation occurred in secondary forest, amounting to 0.31 million ha. Deforestation in the forest area was 0.22 million ha (50.8\%), while outside the forest area (APL) was 0.22 million ha $(49.2 \%)$. Based on forest type, the highest natural forest deforestation occurred in secondary forest, amounting to 0.31 million ha. Deforestation of Natural Forest in the forest area was 0.20 million ha (52.5\%), while outside the forest area (APL) was 0.18 million ha (47.5\%). Deforestation per forest area function in the HK area of 29.0 thousand ha (6.6\%); HL of 39.5 thousand ha (9.0\%); Production Forest of 154.8 thousand ha (35.2\%), consisting of: HPT of 41.6 thousand ha (9.5\%); HP of 85.6 thousand ha (19.5\%); HPK of 27.6 thousand ha $(6.3 \%)$. Deforestation outside forest areas or APL is 216.1 thousand ha (49.2\%) [6].

Deforestation events that occur in tropical areas to become agricultural land are events that occur as changes in land use that have an impact on biodiversity, soil, degradation and the ability of the earth to support human needs (Lambin et al., 2003). This change will change the existing habitat around deforested land. At first the forest was in intact condition but in line with economic growth, a source of funding was needed by exploiting natural resources, especially forests [7].

The pattern of changes in forest cover in Indonesia is closely related to the growth rate of social and economic development. The higher the rate of socio-economic growth will encourage a decrease in forest cover [7]. This study aims to determine the effect of economic growth and population on deforestation in Nusa Tanggara Barat Province.

\section{Method}

In general, this research is descriptive analysis. This study uses a secondary database for analysis and is assisted by mapping techniques with Geographic Information Systems (GIS). Research Research was conducted for 6 months from March - August 2020 with the location under study, namely West Nusa Tenggara Province. The tools and materials used are map processing tools, Landsat 8 image data for 2013 - 2019. The making of spatial database units is expected to be able to collect and manage various data related to regional development. The data used are secondary data from 2013 to 2019 periodic observation data based on constant 2010 prices obtained from the Central Statistics Agency (BPS), the Department of Agriculture, and the Regional Development Planning Agency (BAPPEDA) of West Nusa Tenggara Province 
The research was carried out starting with image pre-processing (image improvement, composite image creation, geometric correction, rectification, radiometric correction, and mosaic image creation), digitizing and interpreting Landsat 8 satellite imagery then spatial analysis with a digitization overlay of the obtained land cover and calculating the rate. change in rate of change in land cover. to calculate the rate of deforestation. To determine the effect of economic growth and population on deforestation in West Nusa Tenggara Province, multiple linear regression is used. The models to be estimated are:

$\mathrm{Y}=\mathrm{a}+\mathrm{b}_{1} \mathrm{X}_{1}+\mathrm{b}_{2} \mathrm{X}_{2}$

Where: $\mathrm{Y}=$ Area of deforestation (hectares)

$\mathrm{X}=$ namely $\mathrm{X}_{1}$ : economic growth $(\%), \mathrm{X}_{2}$ : population (people)

\section{Results and Discussion}

\subsection{Condition of West Nusa Tenggara Province}

The area of NTB Province reaches $20.164,84 \mathrm{~km} 2$ and consists of two main islands, namely Lombok Island and Sumbawa Island, as well as hundreds of small islands. Of the 421 islands in NTB, only 40 islands are inhabited by residents while the rest are uninhabited islands. West Nusa Tenggara (NTB) province is located at 115o46 '- 119o5' east longitude and 8o 10 '- 9o 5' south latitude.

Population is the subject and object of development, so information on the quantity and quality of the population itself is needed in development. The total population of NTB Province in 2019 was 5.07 million people. This number increased by 59,416 people compared to 2018 . The population distribution in NTB Province is relatively uneven, this can be seen from the very varied population density.

One of the economic indicators that reflects the productivity of a region's economy is Gross Regional Domestic Product (GRDP). The NTB Province GRDP in 2019 reached IDR 132.67 trillion with economic growth contracting by 4.01 percent. Although the value of GRDP in NTB has continued to increase since 2012, its economic growth has fluctuated greatly. In 2015, NTB's economic growth reached its highest point of 21.76 percent. Then it fell quite drastically in 2016 to 5.82 percent. Even in 2018 the economic growth of NTB contracted by 4.56 percent.

\subsection{Forest conditions and deforestation in West Nusa Tenggara}

Forest Condition in 2014 The total forest area in 2014 was 832,245.30 Ha from 1,970,900 $\mathrm{Ha}$, the total area of West Nusa Tenggara Province consisting of Lombok Island, Sumbawa Island and other small islands. Meanwhile, the forest condition in 2015 was 780,473.68 Ha. There was a reduction in forest class this year. Forest conditions in 2016 covering an area of $752,649.03 \mathrm{Ha}$, have decreased again in the forest class in West Nusa Tenggara Province. Forest conditions in 2017 covering an area of 743,521.53 hectares, again experienced a decline in forest class. Forest land cover in 2018 is an area of 735,606.45 ha. The condition of the forest in 2019 was 729,974.34 Ha and experienced a decrease in the total forest area, although the increase was in plantation forest and secondary forest. For more details, see Table 1, while the distribution of forest and deforestation can be seen in Figure 1. 
Table 1. Forest Conditions in West Nusa Tenggara Province, 2013 - 2019

\begin{tabular}{|c|c|c|c|c|c|c|c|c|}
\hline No & Forest Class & 2013 & 2014 & 2015 & 2016 & 2017 & 2018 & 2019 \\
\hline 1 & $\begin{array}{ll}\text { Primary } & \text { Forest } \\
(\mathrm{Hp}) & \end{array}$ & $503.087,71$ & $460.906,06$ & $422.261,15$ & $402.515,95$ & $385.190,81$ & $360.394,21$ & $337.193,89$ \\
\hline 2 & $\begin{array}{l}\text { Secondary Forest } \\
(\mathrm{Hs})\end{array}$ & $369.922,92$ & $356.885,60$ & $344.307,76$ & $338.192,53$ & $347.436,11$ & $363.836,07$ & $381.010,15$ \\
\hline 3 & $\begin{array}{l}\text { Primary } \\
\text { Mangrove Forest } \\
(\mathrm{Hmp})\end{array}$ & $5.449,46$ & $4.858,24$ & $4.331,16$ & $3.590,49$ & $2.328,83$ & $2.083,52$ & $1.864,05$ \\
\hline 4 & $\begin{array}{l}\text { Secondary } \\
\text { Mangrove Forest } \\
(\mathrm{Hms})\end{array}$ & $6.973,56$ & $6.969,64$ & $6.965,72$ & $6.524,96$ & $6.630,05$ & $6.998,92$ & $7.188,31$ \\
\hline \multirow[t]{2}{*}{5} & $\begin{array}{l}\text { Plantation Forest } \\
(\mathrm{Ht})\end{array}$ & $2.643,75$ & $2.625,76$ & $2.607,89$ & $1.825,10$ & $1.935,73$ & $2.293,73$ & $2.717,94$ \\
\hline & Total Forest Area & $887.451,12$ & $832.245,30$ & $780.473,68$ & $752.649,03$ & $743.521,53$ & $735.606,45$ & $729.974,34$ \\
\hline
\end{tabular}

Forest conditions in 2019 consisted of primary forest (Hp) covering an area of 337,193.89 ha $(46.19 \%)$, secondary forest (Hs) covering an area of $381,010.15$ ha $(52.20 \%)$, primary mangrove forest (Hmp) covering an area of 1,864, 05 ha $(0.26 \%)$, secondary mangrove forest $(\mathrm{Hms}) 7,188.31$ ha $(0.96 \%)$, plantation forest $(\mathrm{Ht}) 2,717.94$ ha $(0.37 \%)$. Forests in West Nusa Tenggara Province actually fluctuated in area, especially in secondary forests. In contrast to primary forest, there has been a continuous decline until 2018. Changes in forest conditions are influenced by human activities to clear land as needed. For example, clearing land to build houses, opening agricultural areas, making mining for economic purposes. The rate of change in yield forest in the period 2014 to 2019 shows that the average area per year that is easily deforested occurs in secondary forests. During this period there was not only deforestation but also degradation and reforestation. In 2014 to 2018 the average rate of forest change was 11,447 hectares / year. In addition, the deforestation rate according to data from the Ministry of Environment and Forestry in the 2016-2017 period in the Provinces of Nusa Tenggara and Bali covering an area of 8,600 hectares shows not much difference from the results of this study covering an area of 8,424 hectares which only occurred in West Nusa Tenggara Province.

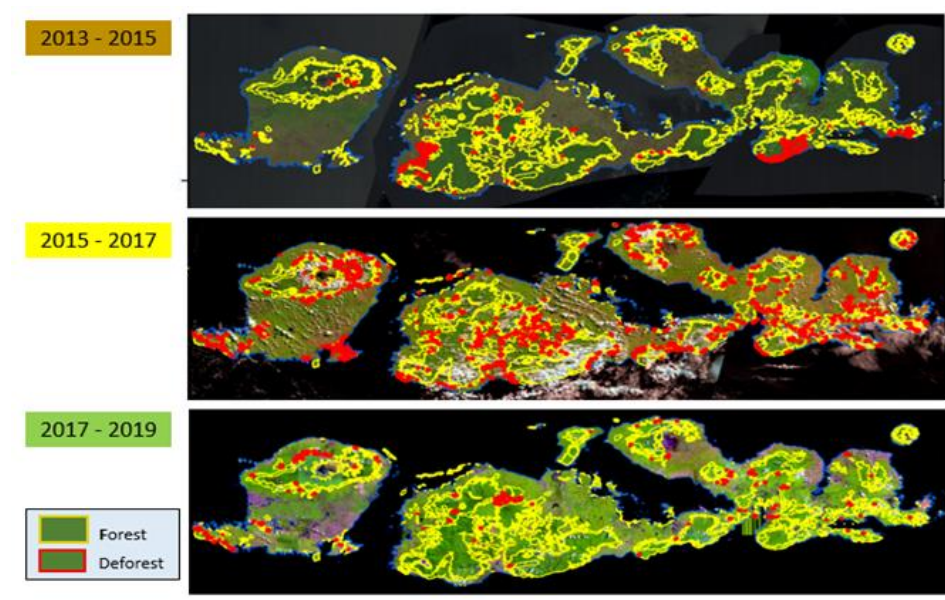

Fig. 1. Changes in Land Cover Result of Interpretation of Landsat 8 Images in West Nusa Tenggara Province 
Deforestation occurs in primary forest class and secondary forest turns into shrubs, open land, agriculture and mining. Deforestation does not only occur in primary forest and secondary forest, it also occurs in the class of plantations turned into agriculture.

\subsection{Relationship of economic growth and population to deforestation}

This study will look at the influence of factors on the extent of deforestation (Y). The effect of the independent variables consisting of economic growth (X1) and population (X2) on the area of deforestation (Y), then there are 2 equation models, but the second equation model can be used. This can be seen in Table 2 .

This study will look at the influence of factors on the extent of deforestation (Y). The effect of the independent variables consisting of economic growth (X1) and population (X2) on the area of deforestation (Y), then there are 2 equation models, but the second equation model can be used. This can be seen in Table 2 .

Table 2. Coefficients ${ }^{\mathrm{a}}$

\begin{tabular}{|c|c|c|c|c|c|c|}
\hline \multirow{2}{*}{\multicolumn{2}{|c|}{ Model }} & \multicolumn{2}{|c|}{ Unstandardized Coefficients } & \multirow{2}{*}{$\begin{array}{l}\text { Standardized } \\
\text { Coefficients } \\
\text { Beta }\end{array}$} & \multirow{2}{*}{$\mathrm{t}$} & \multirow{2}{*}{ Sig. } \\
\hline & & $\mathrm{B}$ & Std. Error & & & \\
\hline \multirow[t]{3}{*}{1} & (Constant) & $2.712 .228,24$ & $257.796,41$ & & 10,521 & ,000 \\
\hline & Population & $-0,39$ & 0,05 & $-1,007$ & $-7,533$ & ,002 \\
\hline & $\begin{array}{l}\text { economic growth } \\
(\%),\end{array}$ & $-946,08$ & 970,75 &,- 130 &,- 975 & ,385 \\
\hline \multirow[t]{2}{*}{2} & (Constant) & $2.617 .940,49$ & $237.751,89$ & & 11,011 &, 000 \\
\hline & Population & $-0,38$ & 0,05 &,- 961 & $-7,732$ & 001 \\
\hline
\end{tabular}

a. Dependent Variable: Total Forest

Thus it can be explained as follows:

- From the regression, it turns out that the area of deforestation (Y) is very significantly influenced by the population (X2), while other factors do not significantly affect the area of deforestation (Y). From the measurement of the multiple regression coefficient, it can be explained that the regression equation is: $\mathrm{Y} 1=-2,617,940.49+0.38 \mathrm{X} 1$

- The results of the measurement of the correlation coefficient for the independent variable $\mathrm{X}$ together with the dependent variable $\mathrm{Y}$ show the number $\mathrm{R}=0.96$. The results of the measurement of the coefficient of determination of the independent variable with the dependent variable $\mathrm{Y}$ show the number $\mathrm{r}^{2}=96.3 \%$ and epsilon $3.7 \%$.

- The effect of population $\left(\mathrm{X}_{1}\right)$ on the area of deforestation $(\mathrm{Y})$ is very significant, meaning that every increase in the population of one level (person) will increase the area of deforestation by 0.38 hectares per person.

From the measurement results of the correlation coefficient, it can be seen that it turns out that among the population $\left(\mathrm{X}_{1}\right)$, in Cibinong District there is a significant (significant) correlation. From the coefficient of determination, it can be seen that the population $\left(\mathrm{X}_{1}\right)$ in Cibinong District is greater when compared to the contribution of epsilon factors to forest area (Y) in Cibinong District. 


\section{Conclusion}

Based on the results of the above research, it can be concluded that (1) West Nusa Tenggara Province from 2013 to 2019 there has been a change in land use, namely the reduced forest area and generally turned into settlements, and (2) Deforestation in West Nusa Tenggara Province is influenced by population growth and is not influenced by economic growth.

\section{References}

[1] D. Inventarisasi et al., INDONESIA. 2018.

[2] A. Widarjono, "Penduduk dan pertumbuhan ekonomi di Indonesia: Analisis kausalitas," Econ. J. Emerg. Mark., vol. 4, no. 2, pp. 147-169, 2016.

[3] M. Suparmoko, "Peranan Sumber Daya Alam dan Lingkungan dalam Pembangunan," Ekon. Sumber Daya Alam dan Lingkung., pp. 1-43, 2016.

[4] S. Alam, "Perladangan Berpindah ( Studi Kasus Petani Hutan Kemiri Rakyat Kabupaten Maros )," vol. 2, no. 3, pp. 280-289.

[5] FWI, “Angka Deforestasi Sebagai “ Alarm ' Memburuknya Hutan,” For. Watch Indones., p. 18, 2019

[6] A. Damarraya, M. Ratnasari, and D. F. P. Rhama, "Deforestasi Indonesia Tahun 2017-2018," Ecum. Rev., vol. 64, no. 2, pp. 1-167, 2019.

[7] H. Dwiprabowo, D. Djaenudin, I. Alviya, and D. Wicaksono, DINAMIKA TUTUPAN LAHAN: Pengaruh Faktor Sosial Ekonomi, no. May. 2014. 